\title{
The next frontier for measurement and evaluation: Social impact measurement for impact investing and market solutions
}

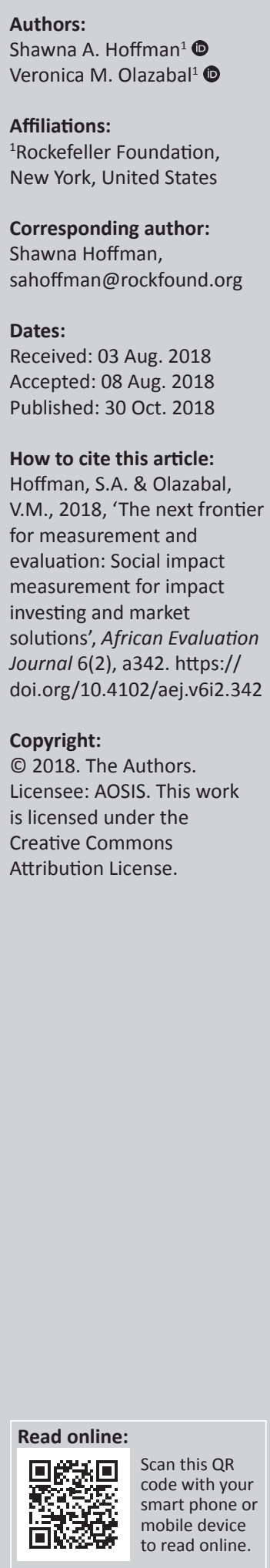

Having invested in the architecture for the field of impact investing, and consistent with its long-standing commitment to advancing development and prosperity in Africa, The Rockefeller Foundation is proud to support this special edition of the African Evaluation Journal focused on social impact measurement in Africa.

\section{Introduction}

The 2015 adoption of the Sustainable Development Goals (SDGs) marked a breakthrough moment for the international community. For the first time, there was consensus among the 193 countries that constitute the United Nations General Assembly on what the global development priorities ought to be and a roadmap for achieving them. At the same time, the articulation of these priorities brought the importance of 'transformative development' solutions - those that move beyond government-led development efforts and mobilise unconventional change agents - squarely into focus (Meyer et al. 2018). Among those solutions, innovative finance, impact investing and other market-based approaches stand out as perhaps the most promising levers for change.

A study by the UN Sustainable Development Solutions Network found that if substantial progress towards the SDGs is to be made globally, an additional $\$ 1.3$ trillion will be needed each year (Meyer et al. 2018; Organisation for Economic Co-operation and Development [OECD] 2017). This represents over nine times the amount that countries receive as official development assistance, an amount that peaked in 2016 at $\$ 142.6$ billion and is not expected to increase further. The world's lowest income countries - the majority of which are in Africa - face an average \$342-\$355 million annual funding deficit (Schmidt-Traub 2015). This shortfall serves as a stark reminder that the most complex and intractable social, political and environmental challenges cannot be solved with development aid and philanthropic dollars alone; private capital is urgently needed to fill the financing gap and move the needle on the SDGs. The 2015 Addis Ababa Action Agenda, developed out of the Third International Conference on Financing for Development, called on businesses and investors to innovate and use impact investment mechanisms and solutions to help solve Africa's greatest development challenges (United Nations 2015).

Innovative finance, impact investing and market solutions are expanding the pool of capital available for social and environmental good. In just over a decade, the industry has experienced exponential growth. According to a survey by the Global Impact Investing Network (GIIN) - a network dedicated to increasing the scale and effectiveness of impact investing globally - assets under management in the impact investment sector were $\$ 8$ billion in 2012 and grew almost eightfold to $\$ 60$ billion by 2015 (GIIN 2017; United Nations Development Programme [UNDP] 2015). Today, impact investing has burgeoned into a $\$ 114$ billion global industry, and $15 \%$ of these impact investments are in Africa (UNDP 2015). Director of the United Nations Development Programme's Regional Service Center for Africa, Lebogang Motlana, argued that the continent 'offers potentially the most exciting and largely untapped investment opportunities' - opportunities which should be harnessed 'by mobilizing and channeling the enormous amount of private finance to contribute to the achievement of Africa's transformational development goals' (UNDP 2015).

\section{Building an evidence base}

The difficulty of knowing how to measure social and environmental impact, and lack of evidence of the impact of market solutions have frequently been cited as major risks to the continued growth of the sector. More than ever before, investors face pressure to demonstrate they are generating social good. Self-reported metrics and indicators, such as GIIN's Impact Reporting and Investment 
Standards (IRIS) catalogue of metrics, were helpful, particularly in the earliest days of the industry. Yet they alone do not meet the threshold for robust, measurable and verifiable outcomes and impact. Questions such as 'what difference is this making for people and the planet?' or 'have there been any anticipated consequences - either positive or negative?' or 'how can we use data to manage our impact?' feature prominently in contemporary discourse. Prominent organisations supporting international development evaluation, such as the International Institute for Environment and Development, EvalSDGs and EvalPartners, have posited the critical role that producing new evidence and data can play towards fostering transformative development (Meyer et al. 2018).

This edition of the African Evaluation Journal explores the dynamic and evolving intersection of impact investing and other market-based solutions with measurement and evaluation. Importantly, this edition charts key conversations on innovations in evaluation in Africa, ${ }^{1}$ highlights the increasing number of B Corps across East Africa and lauds progress among people using business and economic principles as forces for good. In turn, it also reinforces the African Evaluation Association's (AfrEA) Made in Africa agenda, as well as the South2South Evaluation (S2SE) objective of enhancing the influence of southern evaluators in development practice and discourse. ${ }^{2}$ Finally, it shares the findings of an evaluation of 13 companies in Ghana, which serves to generate an improved understanding of the social impacts of a venture capital trust fund. ${ }^{3}$

\section{Evolving the evaluators' toolkit}

Evaluation, as a professional field which traces its roots back to the 1930s, experienced significant growth following the Second World War (Rossi, Lipsey \& Friedman 2004). By the 1950s, evaluations of primarily publicly funded health, housing and education programmes were commonplace, especially in North American countries. At the time, and for roughly the 50 years that followed, evaluation served two core functions: (1) testing and validating the effectiveness of policies, programmes and interventions and (2) compliance and accountability, mainly of governments to their constituents. In both of these cases, evaluation was seen as a retrospective activity - something that tells you what happened after the fact. Accordingly, evaluations of projects, programmes and policies were often carried out after original decision-makers could, in fact, be held accountable.

Since that time, evaluation has grown and evaluation practice has evolved. The world has witnessed the number of national and regional professional evaluations associations surges to more than 150, including, notably, AfrEA (International

1.For more detail, see the article in this edition entitled "Conversations about measurement and evaluation in impact investing'.

2.For more, see article in this edition entitled The B Corp movement in East Africa: An historical shift in the culture of business.

3. For more, see article in this edition entitled Understanding and optimising the socia impact of venture capital: Three lessons from Ghana.
Organization for Cooperation in Evaluation [IOCE] 2017). Likewise, evaluators' skills, approaches and philosophical underpinnings have continually adapted in response to increasingly complex programmes and contexts, and growing pressure from stakeholders for leaner, more forward-looking and learning-oriented approaches.

Today, innovative market-based solutions such as impact investing require evaluators to further evolve their toolkits to meet the needs of a broader and more differentiated and fragmented client base. Conventional evaluation frameworks, theories, tools and approaches are foundational, but ultimately fall short of impact investors' needs for cost-effective, timely data and evidence about social and environmental returns. As Picciotto (2015), former Director-General of the World Bank's Independent Evaluation Group posits

[t]he evaluation discipline, still wedded to traditional public sector program interventions, has not kept pace with this deep seated transformation. It has yet to adapt its methods and processes to the dynamic pace of decision-making favoured by the new actors. In particular, it has failed to find cost-effective ways to deliver adequate and timely evidence to decisionmakers about the likely development impact of interventions. (pp. 5-6)

What is needed, Picciotto argues, is a new 'wave' in evaluation theory and practice (Picciotto 2015). This wave would emphasise ex-ante approaches alongside traditional ex-post evaluations and would shift the unit of analysis away from projects and programmes towards broader markets and systems.

\section{The way forward: Engaging with new market-based actors to advance social outcomes and impact}

Evaluators must be able to differentiate the needs and priorities of market-based decision-makers from more conventional commissioners and users of evaluation in order to be relevant and create value in a context where impact investing and market solutions will be critical for achieving the SDGs. Streams of Social Impact Work, a working paper commissioned by the Rockefeller Foundation in 2015, presents a sample of the differences that evaluators should take into account when engaging with impact investors to build the social impact evidence base (Reisman et al. 2015).

For example, whereas governments and other social sector organisations generally prioritise and make decisions with a view to meeting constituents' needs and maximising positive outcomes, private companies and capital markets generally optimise for financial returns. Two clear implications stem from this. Firstly, measurement and evaluation approaches should be cost-effective and perceived as providing good return-on-investment and contributing to risk management and decision-making for investors. This is different from traditional public sector consumers of evaluation, who often prioritise measurement and evaluation for accountability and compliance. Secondly, capital markets neither always nor 
automatically seek to generate good. Instead, the realisation of positive social outcomes from private capital requires intentionality, impact management and decision-making with public good and social impact in mind. Although the same can be said about governments and non-profit organisations, the risk of unintended or negative outcomes is heightened by market forces - and compounded when not fully taken into account and managed.

Another critical consideration is the role of data and evidence in a competitive marketplace. Governments and non-profit organisations are generally open to sharing their data - with a view to contributing to the public good and global evidence base, as well as to being accountable to taxpayers and other stakeholders. However, the private sector does not necessarily incentivise similar behaviour from impact investors. In fact, where data give companies or investors a competitive edge, there are intrinsic incentives not to share. This dynamic necessitates that evaluators think differently about the availability of companies' information for analysis on the one hand, and on their openness to external sharing of data and evidence of best practices for transparency and benchmarking purposes on the other.

This hints at a fundamental epistemological difference between impact investors and more conventional commissioners and users of evaluation in the public or non-profit sector. While the latter emphasises objectivity of data and analyses, the former have traditionally exhibited comfort deferring to more subjective judgment and experience to guide decision-making. This new framing challenges the ways that evaluators and evaluation practitioners are trained to think and work, and the burden of proof that their stakeholders and clients hold them accountable for delivering.

In summary, how evaluation can work with and add value to impact investing and market solutions is a live and dynamic global conversation. What is clear is that with the continued investment of private capital for social good across Africa, and in the context of the Sustainable Development Agenda, the pressure and opportunity for evaluators to evolve their practice and approaches are palpable and will become even more relevant in the lead-up to 2030.

\section{Acknowledgements Competing interests}

The authors declare that they have no financial or personal relationships that may have inappropriately influenced them in writing this article.

\section{Authors' contributions}

The co-authors of this article played a shared role in researching and authoring its content. The authors are members of The Rockefeller Foundation's Measurement and Evaluation Department. The Rockefeller Foundation is committed to using philanthropic risk capital - through both grants and programme-related investments - to develop and scale the next generation of innovative finance solutions that are needed to close the gap between global development funding needs and the resources that are currently available.

\section{References}

Global Impact Investing Network (GIIN), 2017, Annual impact investor survey, viewed n.d., from https://thegiin.org/assets/GIIN_AnnuallmpactInvestorSurvey_2017_ Web_Final.pdf

International Organization for Cooperation in Evaluation (IOCE), 2017, Internationa mapping of evaluation associations, viewed n.d., from https://www.evalpartners. org/about/international-mapping-of-evaluation-associations

Meyer, W., Naidoo, I., D’Errico, S., Hofer, S., Bajwa, M., Tello Pérez, L.A. et al., 2018, VNR reporting needs evaluation: A call for global guidance and national action, viewed n.d., from http://pubs.iied.org/17446IIED/

Organisation for Economic Co-operation and Development (OECD), 2017, Development aid rises again in 2016 but flows to poorest countries dip, viewed n.d., from http://www.oecd.org/dac/development-aid-rises-again-in-2016-butflows-to-poorest-countries-dip.htm

Picciotto, R., 2015, The fifth wave: Social impact evaluation, Rockefeller Foundation Working Paper, viewed n.d., 2018, from www.rockefellerfoundation.org/ report/5th-wave-social-impact-evaluation/

Reisman, J., Orians, C., Picciotto, R., Jackson, E., Harji, K., MacPherson, N. et al., 2015 Streams of social impact work, Rockefeller Foundation Working Paper, viewed n.d., from www.rockefellerfoundation.org/report/streams-of-social-impact-workworking-paper/

Rossi, P.H., Lipsey, M.W. \& Freeman, H.E., 2004, 'Chapter 1: An overview of program evaluation', in C.D. Laughton (ed.), Evaluation: A systematic approach, pp. 1-31, Sage, Thousand Oaks, CA

Schmidt-Traub, G., 2015, Investment needs to achieve the sustainable development goals, SDSN Working Paper, viewed n.d., from http://unsdsn.org/wp-content/ uploads/2015/09/151112-SDG-Financing-Needs.pdf

United Nations, 2015, Third international conference on financing for development viewed n.d., from http://www.un.org/ga/search/view_doc.asp?symbol=A/CONF. 227/L.1

United Nations Development Programme (UNDP), 2015, Impact investment in Africa: Trends, constraints and opportunities, viewed n.d., from http://www.undp.org/ content/dam/undp/library/corporate/Partnerships/Private $\% 20$ Sector/Impact $\% 20$ Investment $\% 20$ in $\% 20$ Africa/Impact $\% 20$ Investment $\% 20$ in $\% 20$ Africa_Trends, $\% 20$ Constraints $\% 20$ and $\% 200$ pportunities.pdf 